\title{
Persistence of infectious pancreatic necrosis virus (IPNV) in scallops Pecten maximus
}

\author{
Stein Håkon Mortensen ${ }^{1}$, Evelyne Bachere ${ }^{2}$, Ghislaine Le Gall ${ }^{2}$, Eric Mialhe ${ }^{2}$ \\ ${ }^{1}$ Institute of Marine Research, Department of Aquaculture, PO Box 1870, N-5024 Bergen-Nordnes, Norway \\ ${ }^{2}$ IFREMER, U.R.P.I.G.M., PO Box 133, Ronce-les Bains, F-17390 La Tremblade, France
}

\begin{abstract}
Infectious pancreatic necrosis virus (IPNV), serotype N1 isolated from scallops Pecten maximus in Norway, was propagated and used in both inoculation and bath challenge experiments with scallops in vivo. Although virus titers measured in scallop tissues decreased, depuration of virus was not complete during the experimental periods. IPNV was still detectable 11 mo after injection. The highest virus titer was found in the hepatopancreas, but virus was also detectable in other tissues, as well as in the hemolymph. After a bath challenge, uptake of IPNV was shown. Virus was present in hepatopancreas, gonad, kidney, mantle, gill, rectum and in the hemolymph $1 \mathrm{~d}$ after the uptake. The titer was highest in the hepatopancreas where virus was detectable at the end of the experiment, $50 \mathrm{~d}$ after challenge. Virus levels in the rectum decreased below detectable levels after Day 30 . Titers decreased rapidly in the hemolymph where no virus could be detected after Day 8 . Challenges did not result in increased mortality or in clear pathological changes in the scallops. No evidence of viral replication within the scallops was found.
\end{abstract}

\section{INTRODUCTION}

In July 1988, mortalities affected both spat and adult scallops Pecten maximus at a shellfish hatchery near Bergen, western Norway. Infectious pancreatic necrosis virus (IPNV) serotype N1 (Christie et al. 1988) was isolated from moribund adult scallops (Mortensen et al. 1990).

IPNV belongs to the virus family 'Birnaviridae' (Dobos et al. 1979, Dobos \& Roberts 1983, Brown 1984), and viruses from this family have been isolated from several species of marine invertebrates (Hill 1976, Bovo et al. 1984, Lo et al. 1988).

It is still unclear whether the aquatic birnaviruses might act as pathogens for bivalve molluscs, although Hill \& Alderman (1979) reported moderate pathological changes in oysters infected with 2 aquatic birnaviruses isolated from the clam Tellina tenuis and the oyster Ostrea edulis.

It has been shown that isolates from Tellina tenuis and from oysters are biochemically and serologically different from the major aquatic birnavirus serotypes (Hill 1976, Underwood et al. 1977). The aquatic birnaviruses have thus been divided into 2 serogroups, with the IPNV serotypes in serogroup I, and the abovementioned shellfish isolates, together with a few isolates from fish (Hill 1982, Olesen et al. 1988), in serogroup II. The recent isolation of an aquatic birnavirus serogroup II from an epizootic of salmonid fish (Ahne et al. 1989), and the facts that IPNV has been isolated from marine invertebrates and that shellfish isolates of IPN or IPN-like viruses may induce typical signs of infectious pancreatic necrosis in rainbow trout fry (Hill 1982), might indicate that viruses from the 2 serogroups are not strictly specific for fish and shellfish respectively.

As IPNV may be transmitted via faeces and sexual products from infected fish (Wolf et al. 1963) and with decaying infected fish, the virus might subsequently be associated with bivalve molluscs which filter and accumulate particles from the environment. The hepatopancreas is the major organ involved in depuration of digested matter, and a finding of virus in the hepatopancreas might thus indicate a contamination without pathological significance. However, the total depuration of foreign particles in bivalve molluscs is known to be slow (Stauber 1950, Hay \& Scotti 1986), and the bivalve molluscs are considered to serve as 
vectors and reservoirs of various viruses (Mason \& MacLean 1962, Metcalf \& Stiles 1965, Feng 1966. Canzonier 1971, Hay \& Scotti 1986) including aquatic birnaviruses (Hill et al. 1984).

Our aim was to study the possible role of scallops as vectors for aquatic birnaviruses, and a series of experiments was performed in order to answer some of the questions regarding the virus pathogenicity, persistence, uptake and distribution in scallops.

\section{MATERIALS AND METHODS}

Animals. All experiments were performed with adult scallops Pecten maximus, acclimatized to laboratory conditions. IPNV was not detected in hepatopancreas samples from control scallops prior to the infection experiments.

The first injection experiment was performed on scallops with an average shell height of approximately $10 \mathrm{~cm}$, originating from the bay of St. Brieuc, northern Brittany, France. The scallops were kept at $11^{\circ} \mathrm{C}$ in a $60 \mathrm{l}$ plastic tank with recirculating seawater of salinity 28 to $32 \%$ and fed a suspension of Chaetoceros calcitrans.

Scallops used in the other injection and bath experiments were collected by divers near the island of Sotra, western Norway. The scallops had an average shell height of approximately $12 \mathrm{~cm}$. The scallops were kept at 10 to $12^{\circ} \mathrm{C}$ in $250 \mathrm{l}$ aquaria with running seawater of salinity 34 to $35 \%$, and fed a suspension of Skeletonema costatum occasionally supplemented with Isochrysis galbana and Tetraselmis suecica.

Virus. The virus used was IPNV, serotype N1 isolated from Norwegian scallops Pecten maximus (Mortensen et al. 1990).

Cell culture. The rainbow trout gonad (RTG-2) cell line (Wolf \& Quimby 1962) was used in virus propagations, detections and titrations. Cells were cultured at $20^{\circ} \mathrm{C}$ in Earle's modification of minimum esential medium (EMEM) (Flow) supplied with $10 \%$ foetal bovine serum (Flow), $1 \%$ non-essential amino acids (Flow), $10 \mathrm{ml} \mathrm{L-glutamine}(200 \mathrm{mM}$ ) and $10 \mathrm{ml}$ Gentamicin solution (10 $\left.\mathrm{mg} \mathrm{ml}^{-1}\right)$ per liter As confluent cell layers of the RTG-2 cell line are known to produce interferon (Okamoto et al. 1983) all plates were prepared the day before use, adding 25 to 30000 cells per well (ca $9 \times 10^{4} \mathrm{~cm}^{-2}$ ).

Virus titrations. Virus titrations were performed by end-point dilutions on RTG-2 cell layers in 96-well Nunclon microtiterplates using 12 wells per dilution. Infected cell layers were identified by the cytopathic effect $6 \mathrm{~d}$ after inoculation. Virus titers were calculated as TCID $_{50} \mathrm{ml}^{-1}$ or TCID $_{50} \mathrm{~g}^{-1}$ tissue according to the method of Reed \& Muench (1938). In cases of doubt,
$50 \mu l$ supernatants from the wells were inoculated onto fresh RTG-2 cell cultures and incubated another $6 \mathrm{~d}$.

Virus detections. For virus detections, $500 \mu$ filtrate of $1: 49$ dilutions of tissues in EMEM cell culture medium were inoculated onto RTG-2 cell cultures in $25 \mathrm{~cm}^{2}$ Nunclon tissue culture flasks. Supernatants $(50 \mu \mathrm{l})$ from the flasks were transferred to new cell cultures twice (Expts $3 \& 4$ ).

Histology. Tissue samples were fixed in buffered $4 \%$ formol, embedded in paraffin, sectioned, stained with Hematoxylin-Erythrosin-Saffron and observed at 40 to $400 \times$ magnification under a light microscope.

Virus challenges. Four virus challenges were performed 3 by injection (Expts 1 to 3 ) and 1 by bath (Expt 4).

Expt 1: This experiment was performed to determine the changes in the total virus content in the scallops after injection. Ten scallops were each inoculated with $1 \mathrm{ml}$ of a viral suspension diluted in EMEM having a titer of $10^{70} \mathrm{TCID}_{50} \mathrm{ml}^{-1}$. Equal portions of the viral suspension were injected into the branchial vein, the hepatopancreas and the adductor muscle. One scallop was sacrified $20 \mathrm{~h}$ after inoculation, and 3 scallops at each of Days 7, 14 and 21 after inoculation. The adductor muscle was removed, and the rest of the tissue was homogenized in $100 \mathrm{ml}$ sterile seawater with an Ultra-turrax homogenizer. The homogenate was centrifuged twice for $30 \mathrm{~min}$ at $5500 \times g$ at $10^{\circ} \mathrm{C}$ in a Beckman L8-60M ultracentrifuge. Virus titers of the homogenates were determined as described above.

The virus stock suspension used for inoculations was diluted 1:99 with sterile seawater and incubated at $11^{\circ} \mathrm{C}$. Titrations were performed after $24 \mathrm{~h}$ and at Days $4,7,14$ and 18 as described above.

Expt 2: To determine the distribution of virus in different organs, 17 scallops were each injected with $1 \mathrm{ml}$ of virus suspension with a titer of $10^{7.3}$ TCID $_{50}$ $\mathrm{ml}^{-1}$ as described above. Two weeks after inoculation the 16 surviving scallops were sacrified (one died during the experiment). Tissue samples of approximately equal size were taken from hepatopancreas, kidney, the tip of the gonad (ovary) posterior to the lobe of the intestine, mantle, adductor muscle, and gill of each scallop. The pieces were pooled, diluted in EMEM cell culture medium, pounded in a Stomacher Lab-Blender 80, and filtered through $0.2 \mu \mathrm{m}$ disc filters. In addition $500 \mu \mathrm{l}$ hemolymph was drawn from the branchial vein of each specimen, pooled, and filtered. All samples were titrated as described above.

Expt 3: A long-term experiment was performed using 90 scallops, each injected with $1 \mathrm{ml}$ of virus suspension with a titer of $10^{7.3} \mathrm{TCID}_{50} \mathrm{ml}^{-1}$ as described above. Each of 30 control scallops was injected with $1 \mathrm{ml}$ of EMEM cell culture medium. 
Five scallops were sacrified at each of 17 samplings until Day 193 after inoculation. One scallop was sacrified at Days 234, 262, 296 and 333. Hepatopancreas was removed from each scallop, kept separate, and virus titrations were performed as described above. Pieces of hepatopancreas were sampled for histological examination at Days 11, 25 , $39,52,66,84,193,234,262,296$ and 333. Hemolymph was sampled at Days 5, 15, 25, 51, 126, 158, 193, 234, $262,296,333$, and virus titrations were performed as described above (see Table 1). From Day 66 pooled samples from different organs (as described above + rectum) were prepared at each sampling. Faeces samples were collected from the tanks 3 times between. Days 120 and 140 after inoculation.

Control scallops were sacrified at the end of the experiment, and pieces of hepatopancreas were dissected for virus detections as described above.

The suspension of IPNV in EMEM used to inoculate the scallops was stored in a refrigerator at $5^{\circ} \mathrm{C}$ and titrated 11 times during the experimental period.

Virus recovered from hemolymph, intestine, gill and mantle samples collected at Day 126 was sent to Norbio a/s, Bergen, Norway, for serotype verification by ELISA.

Expt 4: A bath challenge was performed by exposing 60 scallops to IPNV in a $250 \mathrm{l}$ aquarium containing 100 I seawater to which had been added a virus suspension to a final titer of $10^{4.5} \mathrm{TCID}_{50} \mathrm{ml}^{-1}$. A further $100 \mathrm{l}$ of seawater was added after $3 \mathrm{~h}$, a slow flow (ca $11 \mathrm{~min}^{-1}$ ) was started after $6 \mathrm{~h}$, and a normal flow (ca $31 \mathrm{~min}^{-1}$ ) was started after $12 \mathrm{~h}$. The temperature was kept at $11^{\circ} \mathrm{C}$ throughout the experiment.

Five scallops were sacrified at each of 12 samplings until Day 50 after exposure (see Fig. 4, Table 2). Before dissections the scallops were kept in a tank with clean, running seawater for $2 \mathrm{~h}$, flushed twice with phosphatebuffered saline containing Tween 80 (0.05\%) and thereafter twice with sterile seawater. Samples from hepatopancreas were kept separate. Samples from other organs and from hemolymph were pooled. Pieces of hepatopancreas, kidney and gonad were fixed for histological examinations at each sampling. Virus titrations and detections were performed as described above.

\section{RESULTS}

\section{Expt 1}

The virus titer present in the scallops decreased from $10^{7.0} \mathrm{TCID}_{50} \mathrm{ml}^{-1}$ at the time of inoculation to approximately $10^{5.1} \mathrm{TCID}_{50} \mathrm{ml}^{-1}$ after $3 \mathrm{wk}$ (Fig. 1). The titer of the virus stock suspension diluted 1:99 in sterile seawater and incubated at $11{ }^{\circ} \mathrm{C}$ showed a slight decrease. No scallops died during the experimental period.

\section{Expt 2}

Virus titers of pooled samples from different organs (hepatopancreas, kidney, the tip of the gonad, mantle, adductor muscle, gill and hemolymph) of 16 inoculated scallops are shown in Fig. 2. The highest titer $110^{5.8}$

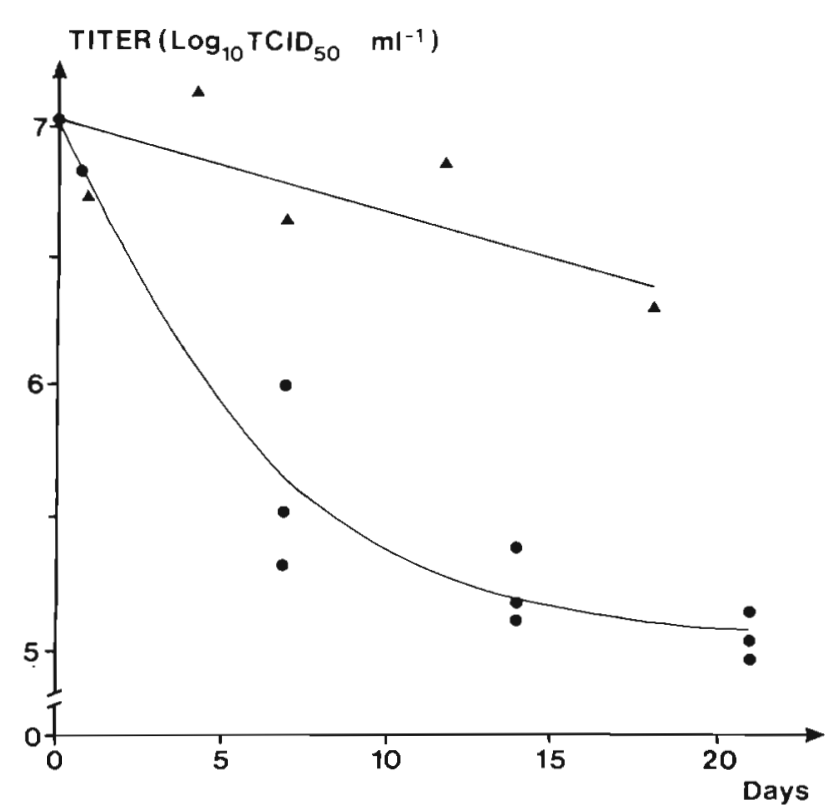

Fig. 1. Pecten maximus. Titer $\left(\log _{10} \mathrm{TCID}_{50} \mathrm{ml}^{-1}\right)$ of IPNV in whole scallops $(\bullet)$ and in seawater at $11^{\circ} \mathrm{C}(\mathbf{\Delta})$. Each point represents the virus titer from one individual scallop kept in a recirculating water system

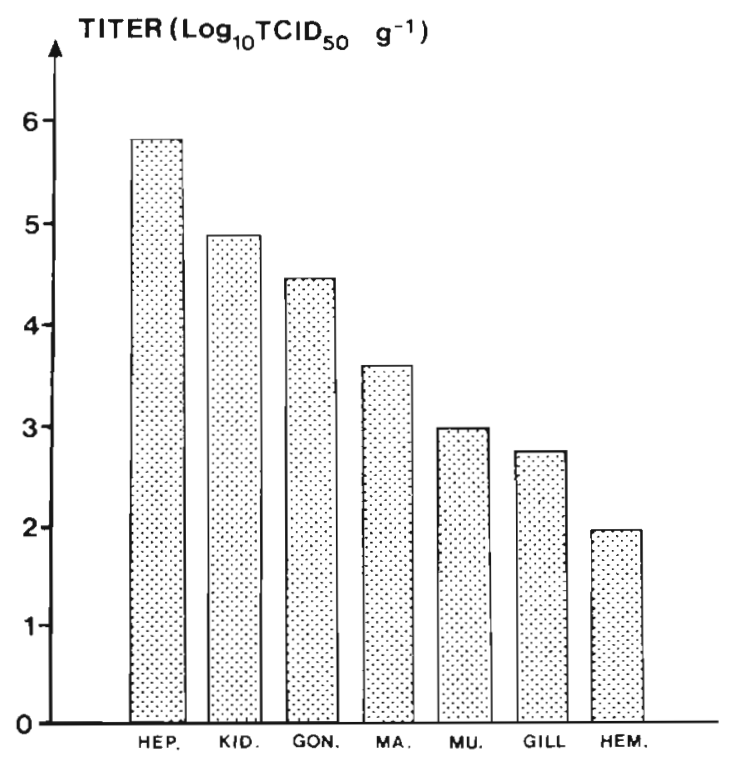

Fig. 2. Pecten maximus. Titer of IPNV $\left(\log _{10} \mathrm{TCID}_{50} \mathrm{~g}^{-1}\right.$ tissue) in scallops $14 \mathrm{~d}$ after virus injection. Each value represents the virus titer in a pooled sample from tissue samples of 16 scallops. Samples were homogenates of hepatopancreas (HEP), kidney (KID), the tip of the gonad (GON), mantle (MA), muscle (MU), gill and hemolymph (HEM) 
$\mathrm{TCID}_{50} \mathrm{~g}^{-1}$ tissue) was detected in the hepatopancreas sample, and the lowest $\left(10^{2.0} \mathrm{TCID}_{50} \mathrm{ml}^{-1}\right)$ in the hemolymph. One scallop died during the experimental period.

\section{Expt 3}

The virus titers of hepatopancreas tissue seemed to stay at a relatively stable level (ca $10^{5.7} \mathrm{TCID}_{50} \mathrm{~g}^{-1}$ tissue) until $3 \mathrm{wk}$ after inoculations (Fig. 3). A rapid decline from ca $10^{5.7}$ to $10^{3.6}$ TCID $_{50} \mathrm{~g}^{-1}$ tissue occurred from Day 20 to Day 39. The titers varied between $10^{4.5}$ and $10^{3.0} \mathrm{TCID}_{50} \mathrm{~g}^{-1}$ tissue during the rest of the experimental period, but showed a slight general decline (Fig. 3). At Day 333 the virus concentration was below titratable level (ca $10^{2.5} \mathrm{TCID}_{50} \mathrm{~g}^{-1}$ ).

Virus was detected in different organs throughout the experimental period. As shown in Table 1, virus titers were determined in filtered hemolymph at Days 5, 15, 25 and 51. Later virus was detected in the hemolymph at Days 126 and 234, but not at Days 158, 262, 296 and 333. Virus reisolated at Day 126 was verified as IPNV serotype N1. Virus could not be detected in the 3 faeces samples.

Virus was not detected in hepatopancreas samples from control scallops.

Histological examinations of hepatopancreas tissue did not reveal any morphological changes. Two virusinoculated scallops and one control scallop died during the experimental period.

The titer of the IPNV suspension used in the inoculations and kept refrigerated declined from $10^{7.6}$ to $10^{3.3}$ $\mathrm{TCID}_{50} \mathrm{ml}^{-1}$ during the 11 mo experimental period.

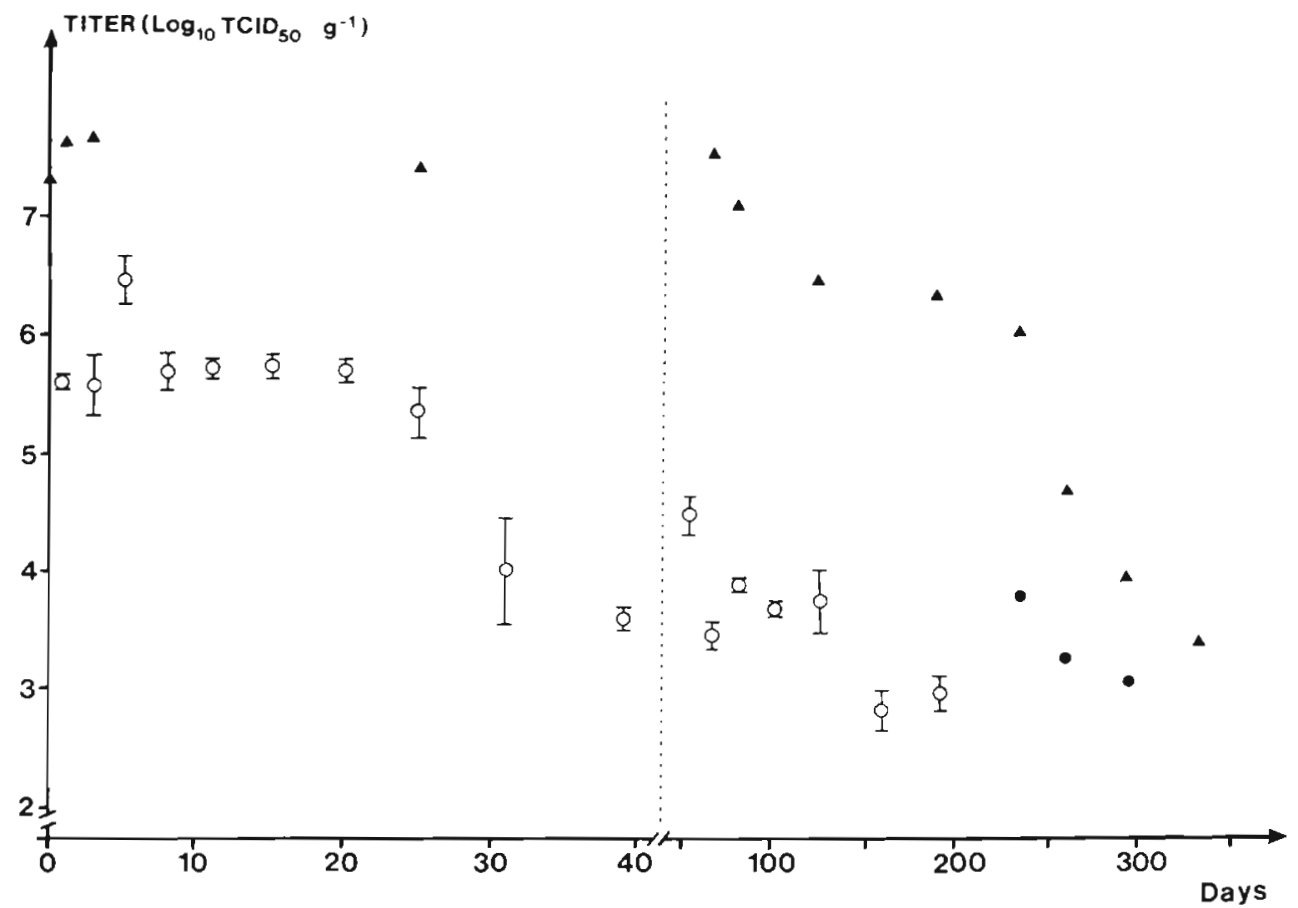

Table 1. Pecten maximus. Titers of IPNV $\left(\log _{10} \mathrm{TCID}_{50} \mathrm{~g}^{-1}\right.$ tissue) in different organs of scallops after virus inoculation by injection: kidney (Kid.), gonad (Gon.), mantle (Ma), adductor muscle (Mu.), gill, rectum (Rect.) and hemolymph (Hem.) $\left(\log \mathrm{TClD}_{50} \mathrm{ml}^{-1}\right)$. Each value represents a pooled sample from 5 scallops, except for the last 4 samplings (1 scallop each). +: Sample containing virus below the level of countability by end point dilution (ca $10^{2.5} \operatorname{TClD}_{50} \mathrm{~g}^{-1}$ ); -: sample where virus was not detected

\begin{tabular}{|rccccccc|}
\hline Day & Kid. & Gon. & Ma. & Mu. & Gill & Rect. & Hem. \\
\hline 1 & & & & & & & \\
3 & & & & & & & \\
5 & & & & & & & 1.6 \\
15 & & & & & & & 1.4 \\
25 & & & & & & & 1.5 \\
51 & & & & & & & 1.8 \\
66 & & 3.0 & & - & + & 3.0 & \\
84 & + & 3.5 & + & + & + & 3.0 & \\
99 & 2.9 & 3.0 & + & - & + & 3.4 & \\
126 & 3.0 & 2.9 & + & - & + & 3.7 & + \\
158 & - & + & + & + & + & + & - \\
193 & + & + & + & + & - & + & - \\
234 & + & 3.5 & + & - & + & + & + \\
262 & + & + & + & + & + & + & - \\
296 & + & + & + & + & - & + & - \\
333 & + & + & - & + & + & + & - \\
\hline
\end{tabular}

\section{Expt 4}

After the bath challenge virus titers of hepatopancreas tissue declined rapidly, from an average of $10^{5.1}$ to approximately $10^{3.5} \mathrm{TCID}_{50} \mathrm{~g}^{-1}$ tissue during the first week (Fig. 4). Virus was detected in the hepatopancreas from all individuals, except from one scallop on the last day of sampling (Day 50). Hepato-
Fig. 3. Pecten maximus. Titer of IPNV $\left(\log _{10} \mathrm{TCID}_{50}\right.$ $\mathrm{g}^{-1}$ hepatopancreas tissue) in scallops after the injection of virus. (0) Mean values from 5 individuals. Single values (•) are marked at Days 158, 262 and 296. No value is marked at Day 333, as the titer was below the level of countability by end point dilution ( $\mathrm{Ca} 10^{2.5}$ TCID $_{50}$ $\left.\mathrm{g}^{-1}\right)$. Vertical bars indicate standard error of mean. (a) Titers of the virus suspension, kept refrigerated during the experimental period 
Fig. 4. Pecten maximus. Titer of IPNV $\left(\log _{10} \mathrm{TCID}_{50}\right.$ $\mathrm{g}^{-1}$ hepatopancreas tissue) in scallops after bath exposure. (o) Mean values from 5 individuals. Bars indicate standard error of mean. Single values $(\bullet$ ) are marked at Days $10,13,17$, 30 and 50 due to $1,4,3,2$ and 3 values respectively below the level of countability by end point dilution (ca $10^{2.5}$ TCID $_{50} \mathrm{~g}^{-1}$ ). (a) Virus titers from rectum pooled from 5 individuals. (a) Virus titer from kidney sample at Day 4

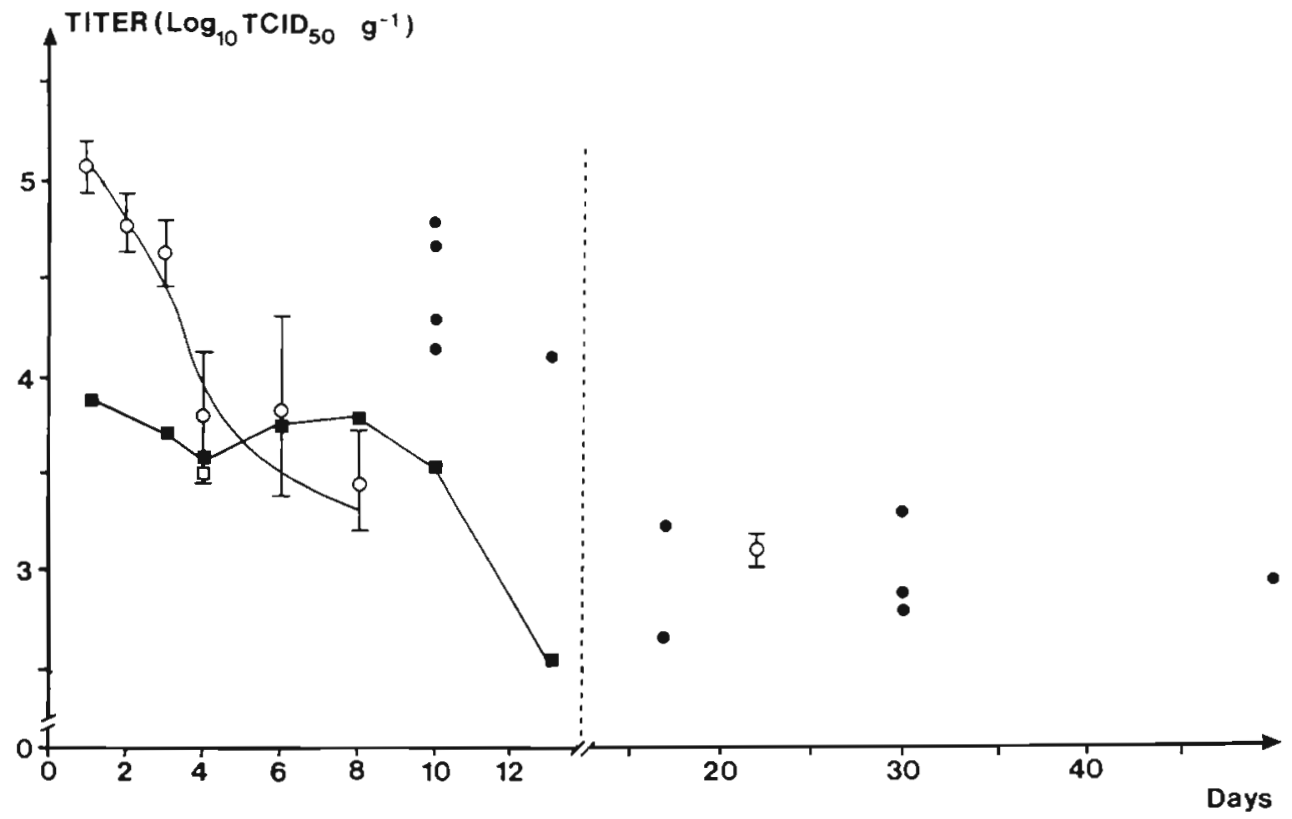

As shown in Table 2, virus was occasionally detected in the gonad, mantle, gill, and in filtered hemolymph. Virus could not be detected in the adductor muscle.

Histological examinations of hepatopancreas, kidney and gonad tissues revealed no clear pathological changes. Highly vacuolized cells and a diffuse organization of the epithelia were observed in the digestive tubules during the first $4 \mathrm{~d}$ of the experiment. The number of hemocytes in the hepatopancreas seemed normal. No scallops died during the experimental period.

\section{DISCUSSION}

Table 2. Pecten maximus. Titers of IPNV in different organs of scallops after bath exposure: gonad (Gon.), mantle (Ma.), adductor muscle (Mu.), gill, and hemolymph (Hem.) $\left(\log _{10} \mathrm{TCID}_{50} \mathrm{ml}^{-1}\right)$. Each symbol represents a pooled sample from 5 scallops. +: Sample containing virus below the level of countability by end point dilution (ca $10^{2.5} \mathrm{TCID}_{50} \mathrm{~g}^{-1}$ ); -: sample where virus was not detected

\begin{tabular}{|cccccc|}
\hline Day & Gon. & Ma. & Mu. & Gill & Hem \\
\hline 1 & + & + & - & + & + \\
2 & - & - & - & + & 1.8 \\
3 & - & - & - & + & + \\
4 & - & + & - & + & - \\
6 & - & + & - & + & - \\
8 & + & + & - & + & + \\
10 & - & + & - & + & - \\
13 & - & - & - & - & - \\
17 & - & + & - & - & - \\
22 & - & - & - & - & - \\
30 & - & - & - & + & - \\
50 & - & + & - & - & - \\
\hline
\end{tabular}

The results shown in Fig. 1 indicate that IPNV injected into scallops was either rapidly inactivated or excreted. The decrease in virus titers of hepatopancreas tissue shown in Fig. 3 occurred approximately $3 \mathrm{wk}$ after inoculation, and the reduction in virus titers in whole scallops seemed thus more rapid than the reduction of virus in the hepatopancreas tissue alone. As reviewed by Sminia \& Van der Knaap $(1986,1987)$ the molluscan hemolymph contains a number of components which might neutralize virus infectivity, such as humoral factors of both enzymatic and non-enzymatic character. A T3 coliphage neutralizing activity in oyster (Crassostrea gigas) hemolymph was recently shown by Bachère et al. (1990). Destruction of IPNV might also occur intracellullarly in circulating hemocytes, as it has been shown that oyster hemocytes may take up virus particles in vitro (Fries \& Tripp 1970). 
The reduction of virus titers might be due to excretion, and our findings of virus in the hepatopancreas and rectum samples in Expts 3 and 4 indicate that both injected and ingested virus could move through the alimentary tract. The highest titers in hepatopancreas in Expts 2, 3 and 4 suggest that the hepatopancreas was the main organ involved in the depuration processes, and may be in accordance with the results of Metcalf \& Stiles (1965) who found that the concentration of ingested enteric viruses increased in oyster hepatopancreas at the same time as the virus concentration decreased in other tissues.

Detections of virus in kidney samples indicated that an excretion of virions maybe also could occur via excretory praducts. Our results might thus be in accordance with Halder \& Ahne (1988) who found that freshwater crayfish Astacus astacus infected with IPNV excreted infective virus particles continuously into the water.

In bivalves, ingested virus may persist sequestered in tissues, and thus appear protected from neutralization and depuration processes (Canzonier 1971, Metcalf \& Stiles 1965, Hay \& Scotti 1986). It was shown in Expt 4 that virus ingested by filtration of contaminated water was present in the hemolymph. In Expt 3 injected virus was present in hemolymph samples as long as $234 \mathrm{~d}$ after injection. A, comparison of results from Expt 2, 3 and 4 indicates that both injected and filtered virus probably circulated with the hemolymph and could reach and persist in different tissues. The fact that the virus titers were highest in the hepatopancreas is in agreement with the results obtained by Canzonier (1971) who showed that most of the Coliphage S-13 accumulated by clams filtering virus-containing water was sequestered in the digestive gland.

The persistence of IPNV in the ovaries of scallops may indicate that the eggs represent a favourable environment for virus. In salmonid fish, vertical transmission of IPNV via the eggs is known (Wolf et al. 1963) and transmission can occur despite iodine treatment of eggs (Bullock et al. 1976). Ahne \& Negele (1985) suggested the virus might be protected in lobes and pores of the egg shell.

In contrast to the results observed after injections, after the bath challenge virus detection in organs other than hepatopatopancreas and rectum was scarce. Mantle and gill tissues contain numerous mucussecreting cells, and the occasional virus detections in mantle and gill might be a result of trapping of virus from the passing water. Di Girolamo et al. (1977) suggested that trapping of virus particles by ion bonding in the mucus of the digestive tract is the principle way of introduction.
Comparing results from these experiments, it seems likely that the scallops were able to inactivate and/or eliminate a virus challenge administrated by bath more efficiently than one administrated by injection. The histological changes observed in sections from hepatopancreas tissue sampled during the first days of the bath challenge experiment probably indicate increased activity in the digestive tubules due to the virus exposure. Lack of obvious histological changes indicates that the isolated IPNV did not act as a pathogen for the scallops.

Throughout the experiments no increase in virus titers was observed, and thus no viral replication was proven. However, in view of the persistence of the virus in different organs, the possibility of a slow rate of replication occurring simultaneously with inactivation and/or excretion processes cannot be excluded.

Acknowledgements. Thanks are due to Lisbeth Harkestad, Ingrid Uglenes and Hari Rudra for excellent technical assistance, to Johan Glette and Karin Pittman for constructive criticism, and to Karen Elina Christie at Norbio a/s who verified the IPNV serotype. This work was supported by The Royal Norwegian Council for Industrial and Scientific Research, grant St 81142 221062, The Norwegian Fishery Research Council, The Regional Development Fund (Norway) and $\mathrm{a} / \mathrm{s}$ Mowi.

\section{LITERATURE CITED}

Ahne, W., Jørgensen, P. E. V., Olesen, N. J, Fischer-Scherl, T., Hoffmann, R. (1989). Aquatic birnaviruses: virus of the serogroup II isolated from an IPN outbreak in brook trout Salvelinus fontinalis\}. Bull. Eur. Ass. Fish Pathol. 9(1): 14

Ahne, W., Negele, R. D. (1985). Studies of the transmission of infectious pancreatic necrosis virus via eyed eggs and sexual products of salmonid fish. In: Ellis, A. E. (ed.) Fish and shellfish pathology, Academic Press, London, p. $261-269$

Bachère, E., Hervio, D., Mialhe, E., Grizel, H. (1990). Evidence of neutralizing activity against T3 coliphage in oyster Crassostrea gigas hemolymph. Dev. comp. Immunol. 14: 261-268

Bovo, G., Ceschia, G., Giogetti, G., Vanelli, M. (1984) Isolation of an IPN-like virus from adult kuruma shrimp (Penaeus japonicus). Bull. Eur. Ass. Fish Pathol. 4(2): 21

Brown, F. (1984). The classification and nomenclature of viruses: summary of results of meetings of the international commitee on taxonomy of viruses in Sendai. September 1984. Intervirol. 25: 141-143

Bullock, G. L., Rucker, R. R, Amend, D., Wolf, K., Stuckey, H. M. (1976). Infectious pancreatic necrosis: Transmission with iodine-treated and nontreated eggs of brook trout (Salvelinus fontinalis). J. Fish. Res. Bd Can. 33: 1197-1198

Canzonier, W. J. (1971). Accumulation and elimination of coliphage S-13 by the hard clam Mercenaria mercenaria. Appl. Microbiol. 21: 1024-1031

Christie, K. E., Håvarstein, L. S., Djupvik, H. O., Ness, S. Endresen, C. (1988). Characterization of a new serotype of infectious pancreatic necrosis virus isolated from Norwegian Atlantic salmon. Arch. Virol. 103: 167-177 
Di Girolamo, R., Liston, J., Matches, J. (1977). Ionic bonding, the mechanism of viral uptake by shellfish mucus. Appl. environ. Microbiol. 33: 19-25

Dobos, P., Hill, B. J., Hallett, R., Kells, D. T C., Becht, H. Teninges, D. (1979). Biophysical and biochemical characterization of five animal viruses with bisegmented doublestranded RNA genomes. J. Virol. 32: 593-605

Dobos, P., Roberts, T. E. (1983). The molecular biology of infectious pancreatic necrosis virus: a review. Can. J. Microbiol. 29: 377-384

Feng, J. S. (1966). The fate of a virus, Staphylococcus aureus phage 80 , injected into the oyster, Crassostrea virginica. J. Invertebr. Pathol. 8: 496-504

Fries, C. R., Tripp, M. R. (1970). Uptake of viral particles by oyster leucocytes in vitro. J. Invertebr. Pathol. 15: 136-137

Halder, M., Ahne, W. (1988). Freshwater crayfish - a vector for infectious pancreatic necrosis virus (IPNV). Dis. aquat. Org. 4: 205-209

Hay, B., Scotti, P. (1986). Evidence for intracellular adsorption of virus by the pacific oyster, Crassostrea gigas. N.Z. J. mar. Freshwat. Res. 20: 655-659

Hill, B. J. (1976). Molluscan viruses: their occurrence, culture and relationships. In: Proceedings of the first international colloquium on invertebrate pathology. Queens University Press, Kingston, Canada, p. 25-29

Hill, B. J. (1982). Infectious pancreatic necrosis virus and its virulence. In: Roberts, R. J. (ed.) Microbial diseases of fish. Academic Press, London, p 91-114

Hill, B. J, Alderman, D. T. (1979). Observations on the experimental infection of Ostrea edulis with two molluscan viruses. Haliotis 8: 297-299

Hill, B. J., Way, K., Alderman, D. J. (1986). IPN-like birnaviruses in oysters, infection or contamination? In: Vivarès, C. P., Bonami, J.-R., Jaspers, E. (eds.) Pathology in Marine Aquaculture, Montpellier Eur. Aquaculture Soc. Spec. Publ. no. 9, Bredene, Belgium, p. 297

Lo, C.-F., Hong, Y.-W., Huang, S.-Y., Wang, C.-H. (1988). The characteristics of the virus isolated from the gill of clam, Meterix lusoria. Fish Pathol. 23 (3): 147-154

Responsible Subject Editor: W. Ahne, Munich, Germany
Mason, J. O., McLean, M. R. (1962). Infectious hepatitis traced to the consumption of raw oyster. An epidemiologic study. Am. J. Hyg. 75: 90-111

Metcalf, T G., Stiles, W. C. (1965). The accumulation of enteric viruses by the oyster., Crassostrea virginica. J. inf. Dis. 115: 68-76

Mortensen, S. H., Hjeltnes, B., Rodseth, O., Krogsrud, J., Christie, K. E. (1990). Infectious Pancreatic Necrosis Virus, serotype N1 isolated from Norwegian turbot (Scopthalmus maximus), halibut (Hippoglossus hippoglossus) and scallops (Pecten maximus). Bull. Eur. Ass. Fish Pathol. 10(2): $42-43$

Okamoto, N., Shirakura, T., Nagakura, Y., Sano, I (1983). The mechanism of interference with fish viral infection in the RTG-2 cell line. Fish Pathol. 18: 7-12

Olesen, N. J., Vestergård Jørgensen, P. E., Bloch, B., Mellergård, S. (1988). Isolation of an IPN-like virus belonging to the serogroup II of the aquatic birnavirus from dab, Limanda limanda L. J. Fish Dis. 11: 449-451

Reed, L. J., Muench, H. (1938). A simple method of estimating fifty percent end points. Am. J. Hyg. 27: 493-497

Sminia, T., Van der Knaap, W. P. (1986). Immunoreaction in invertebrates with special reference to molluscs. In: Brehélin, M. (ed.) Immunity in invertebrates. SpringerVerlag, Berlin, p. 112-124

Sminia, T., Van der Knaap, W. P. (1987). Cells and molecules in molluscan immunology. Dev. comp. Immunol. 11: $17-28$

Stauber, L. A. (1950). The fate of india ink injected intracardially into the oyster, Ostrea virginica Gmelin. Biol. Bull. mar. biol. Lab. Woods Hole 98: 227-241

Underwood, B. O., Smale, C. J., Brown, F., Hill, B. J. (1977). Relationship of a virus from Tellina tenuis to infectious pancreatic necrosis virus. J. gen. Virol. 36: 93-109

Wolf, K., Quimby, M. C. (1962). Established eurythermic line of fish cells in vitro. Science 135: 1065-1066

Wolf, K., Quimby, M. C., Bradford, A. D. (1963). Eggassociated transmission of IPN virus in trouts. Virology 21: $317-321$

Manuscript first received: May 27, 1991

Revised version accepted: February 12, 1992 